anatomy and physiology of the genito-urinary tract. This part of a textbook is so often woolly and inexact that it is a pleasure to read these interesting presentations which are fully documented and up to date. The symptomatology and investigations of diseases of the urinary tract are next described with particularly valuable practical instructions, especially of the endoscopic work. It is refreshing to see useless but oftrepeated lumber put in its place, as one contributor here deals with the mobility of the rectal mucosa over the prostate.

If one criticism may be made, the recommendation that a sterile catheter specimen is essential in females is certainly open to question, and present-day reluctance to catheterization might be better stressed.

The operative surgical sections are clear and well illusrated, affording descriptions from which the uninitiated may understand how each procedure is performed, a compliment that can all too rarely be paid to such textbook accounts.

This book makes enjoyable reading and has the authentic note of craftsmen speaking of their work. The postgraduate student may read it confident that he is gaining a thorough knowledge of current views and practice.

\section{Inhaled Particles and Vapours}

Proceedings of an International Symposium organized by the British Occupational Hygiene Society. Edited by C. N. Davies. Pp. xi +495 , illustrated. Oxford, London, New York and Paris: Pergamon Press. 1961. $£ .5$.

An International Symposium on Inhaled Particles and Vapours was recently held in Oxford by the British Occupational Hygiene Society. The 38 papers presented there and the discussions that followed them are the subject of this book.

The book is divided into several sections. The first, which is on anatomy and physiology, covers such topics as observations on gas flow in the human bronchial tree with the aid of mass spectrometry, the influence of the mixing of intra-pulmonary gas flow on the deposition of aerosols, and recent knowledge of the properties of the 'lining complex' of alveoli. There then followed sections on physical and chemical aspects of particle retention and on the behaviour of radioactive aerosols after inhalation. Next comes a substantial section on the pulmonary elimination and storage of dust. The final two sections are relatively short and applied, consisting of one on asbestosis and another on selective sampling and pneumoconiosis.

The editor and publishers can be congratulated upon producing in a short time an attractive book which achieves a high standard of presentation. Many of the articles are of great interest, even to the non-specialist.

\section{Ophthalmic Operations}

Seymour Philps, F.R.C.S. Second edition revised by JoHN Foster, M.D., F.R.C.S. Pp. 368, with 456 illustrations. London: Baillière, Tindall \& Cox. 1961. 70s.

The first edition of this text book on eye surgery was written by the late Seymour Philps, who was Surgeon to St. Bartholomew's Hospital and to Moorfields Eye Hospital.

The second edition has been prepared by John Foster, Ophthalmic Surgeon to the General Infirmary at Leeds, and Senior Clinical Lecturer in Ophthalmology, Leeds University. While following the aims of the original author, the book has been brought up to date. It describes in a clear and practical manner the indica- tions and techniques for each ophthalmic operation, and $\varrho$ reflects the international outlook and wide experience of the author.

Some recent techniques in the treatment of retinal $c$ detachments, such as photo-coagulation of MeyerSchwickerath, have been reserved for the next edition. $\overrightarrow{\bar{f}}$

The book is well illustrated, easy to read, and has $\overline{0}$ much to commend it. It is eminently suitable for postgraduate students of ophthalmology, and for the $\overline{\bar{S}}$ ophthalmic surgeon who only operates occasionally.

\section{Progress in Medical Laboratory Technique-I}

Edited by F. J. BAKER, F.l.M.L.T., F.I.S.T., F.R.M.S. $\overrightarrow{0}$ Pp. vii +189 , illustrated. London: Butterworths. I962. 35 s.

We have not yet devised a satisfactory method for distributing knowledge of validated methods from the journals and large laboratories to the smaller laboratory 3 . centres, and this book makes an attempt to do precisely $\omega$ this. It seems that two types of publication are needed; $\infty$ one issued at intervals of several years, giving an account of standard methods which are generally accepted; the 0 other issued irregularly, as occasion arises, giving details of some new principle, procedure, or technique, which $\mathrm{N}$ others besides the authors have found valuable. The $ᄋ$ first type is represented by the big American volumes on standard methods, by Tarnoky's book on biochemical $\vec{c}$ methods, and by the 'Recent Advances in Clinical Pathology'; the second by the broadsheets of the Associa- $\mathbb{D}$ tion of Clinical Pathologists and by the method sheets issued by Unicam and other manufacturers, and to $\&$ limited extent by the Journal of the Institute of Medic Laboratory Technology.

This book falls between these two extremes. Its $\frac{60}{12}$ articles, three on hæmatological serology, two on food poisoning and enterica, one each on mycology, virus $\bar{\partial}$ technique, ethylene oxide sterilization, exfoliative cytology, histopathology, histochemistry and chemical 을 pathology, are each written by a technical expert who describes the methods in such detail that few would $\overrightarrow{\vec{\sigma}}$ have difficulty in following them. In most cases, the 3 reasons for the choice of technique is also clearly $\vec{Z}$ explained, and there is no doubt that this little book $\frac{\vec{F}}{0}$ concentrates much information valuable to the bench worker.

Although the contents are excellent, its real utility seems less certain, because the field covered is very wide and many of the methods require time and skill rarely available in the smaller laboratories.

\section{Enzymes in Clinical Chemistry}

Proceedings of the Second International Sym- $D$ posium on Enzymes in Clinical Chemistry, Ghent, 음 Belgium, April 1961. Pp. vi +128 (numbered 383-5II). London: Butterworths. 1962. 6os. O

A collection of papers from pure and applied $N$ chemistry is reprinted in this volume. The papers $N$ are in either English, French, or German, and unfor- $\omega$ tunately summaries in the three languages are not $\underset{<}{ }$ included. The value of many of the papers is therefore 0 lost to any English-speaking reader whose knowledge $\frac{}{\square}$ of other languages is limited. Many of the papers are in the nature of progress reports, examinations of methods, or academic studies on the properties of $T$ particular enzymes. The data contained in the papers have the usual significance attached to papers in scientific journals, but there appears to be little to justify reprinting in a separate volume. 